\title{
Momentum Concept Learning Using Tracker as a Virtual Experiment Model: Looking at Students' Learning Independence
}

\author{
Bambang Subali ${ }^{1 *}$, Nindy Ulqia ${ }^{2}$, E. Ellianawati ${ }^{3}$ and S. Siswanto ${ }^{4}$ \\ 1,2, ${ }^{3}$ Physics Department, Universitas Negeri Semarang, Semarang, Indonesia \\ ${ }^{4}$ Natural Science Education Department, Universitas Tidar, Magelang, Indonesia
}

*Corresponding Address: bambangfisika@mail.unnes.ac.id

\begin{tabular}{l}
\hline \hline Article Info \\
\hline Article history: \\
Received: November $16^{\text {th }}, 2020$ \\
Accepted: February $19^{\text {th }}, 2021$ \\
Published: April $30^{\text {th }}, 2021$ \\
\end{tabular}

Keywords:

Learning independence; Momentum;

Tracker Software;

Virtual Experiment Model.

\begin{abstract}
Visualization of physical phenomena through modeling and virtual experiment help students to understand the physics concepts. The concept of momentum is quite challenging to explain without the help of virtual experiments. This study aimed to analyze students' independent learning after conducting the learning process on the concept of momentum using Tracker software as a virtual experimental model. This study was quasi-experimental with the purposive sampling technique to determine the control class and the experimental class. There were 42 students involved in this research. The control class was treated by actual experiments on learning, while the experimental class used the Tracker software as a virtual experiment model. The instrument used was questionnaires given at the end of learning to measure students' learning independence. The data were analyzed by using the descriptive statistics method. Learning independence in the control class obtained $51.31 \%$ in the medium category, and the experimental class obtained $60.95 \%$ in the medium category. Although the average achievement was not significantly different, the aspects of responsibility, motivation, and selfevaluation of the experimental class were better than that of the control class.
\end{abstract}

(C) 2021 Physics Education Department, UIN Raden Intan Lampung, Indonesia.

\section{INTRODUCTION}

Active learning can be interpreted as a learning process that requires students to be independent in learning. Learning independence is very important to foster essential aspects of learning achievement. (Ambarsari, et al., 2013). One of the learning methods is the interactive learning method. This method is very appropriate to facilitate students to be more active (Sharma et al., 2010). Rubgay (2018) states that teachers must carry out exciting and innovative learning activities to create good teaching. By implementing the interactive learning method, the learning activities will be more meaningful, enhancing students' opportunities to be actively involved in the learning process. An activity that students can carry out to increase their learning activity is problem-solving. It can train students to think creatively. According to Rohmah and Sutiarso (2017), the problemsolving based-learning develops students' skills in solving problems effectively. Creativity in thinking can produce students who can find solutions to ideas and approaches to a problem they see (Pichailuk \& Luksaneeyanawin, 2015).

Physics learning activities will be more meaningful if equipped with appropriate experimental activities (Anissofira et al., 2017). Learning in the laboratory can help students understand physics's fundamental concepts in real terms (Chiriacescu, 2020). According to Semerci and Aydin (2018), the 
use of technology in learning is an effort to make it easier for students to learn. Therefore, we need media that can help students obtain more accurate data when doing experiments.

Kholida and Latief (2018) discover that the phenomenon of momentum can be displayed and represented in the form of values and graphs through video analysis. Hasibuan et al., (2018) state that learning media's effectiveness can help students understand concepts while learning quickly. One of the media that can help students to experiment is Tracker. Tracker is an Open Source Physics (OSP) Java framework in video analysis (Wee et al., 2015). The device can display real and representative physics symptoms, both in the form of data and graphics. It functions as software of VideoBased Learning (VBL) (Sartika et al., 2019). By employing the tracker software, the investigation of the kinematics parameter will be more accurate (Prima et al., 2016). Through video analysis, data of the object motions can be interpreted by reviewing the relationship between position, speed $(\mathrm{v})$, and time (t) (Kinchin, 2012). Rodrigues and Carvalho (2014) conduct an experimental activity using the Tracker. It is pretty easy and can be carried out individually by students. Sundayana (2016) states that students can be initiative and work separately through tracker software in terms of determining learning objectives, learning methods, and learning outcomes. This activity is addressed as students' learning independence. According to Bartholomew (2017), learning independence can improve students' ability to find out what they need when they study. According to Farahdina (2014), to determine the students' learning independence, indicators are needed. Students' learning independence covers eight indicators: 1) having the learning initiative; 2) can diagnose learning needs; 3) can settle the target and goals of learning; 4) monitor, organize, and control the learning activities; 5) consider adversity as a challenge; 6) utilize and find relevant sources; 7) choose and apply the learning strategy; and 8) evaluate the process, learning result, and self-efficacy.

Technology-based learning as a learning medium is proven to increase students' learning independence (Arista \& Kuswanto, 2018). Learning independence can give students the freedom to explore themselves and hone their ability to learn independently without coercion or orders from others (Mulyono et al., 2018). Self-evaluation is essential in the learning process. It is intended to measure the understanding of the individual in learning (Adams et al., 2012). Independent learning can also be interpreted as self-regulated learning (SRL), which is a skill that helps students in mastering emotions, cognition, and behavior during the learning process (Halem, 2020). Learning independence can be seen from understanding learning using the media or other methods (Sulisworo \& Sutadi, 2017).

Fadholi et al., (2018), in their research, revealed that the collision video analysis using Tracker software could obtain parameter values that are fitted with the theory. Therefore, the tracker software can be used for analysis activities on other videos related to motions. On the other hand, virtual laboratory-based media in learning physics on the momentum material towards students' learning outcomes increased in the attitude competency (Agustriani et al., 2018). However, from several studies related to momentum, only attitude competence can be improved where the students are more enthusiastic in learning physics. Besides attitude competence, students must understand the concept of momentum as well. When learning using the Tracker software, they are still in groups to learn independently. Therefore, this study was conducted to analyze the students' learning independence after completing the learning process on the concept of momentum using the Tracker software as a virtual experimental model. 


\section{METHODS}

In this research, the quasi-experimental design was employed with pretest and posttest control group design. In this design, there were three main activities, as shown in Figure 1.

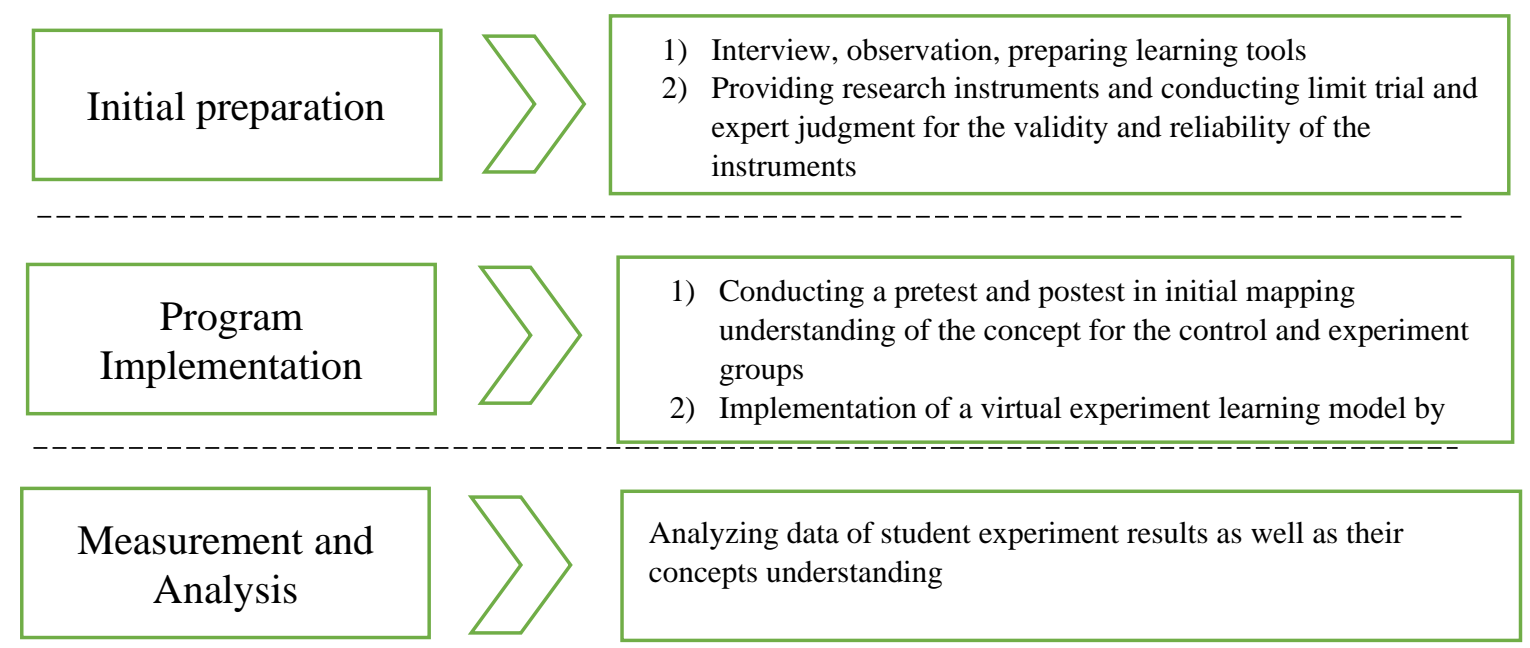

Figure 1. Research Procedure

The research design has a control group but cannot function fully to control external variables that can influence the conduct of the experiment, and the sample is not chosen randomly.

The population in this research was all tenth-grade MIPA students of Islamic High School Al-Azhar 14 Semarang in the $2^{\text {nd }}$ semester. The sample used was MIPA-1 students as the experimental class treated by virtual experimental model and MIPA-2 students the control class treated by real experimental model. Both classes were determined using the purposive sampling technique. Each class consisted of 21 students.

The instrument used in this research was a questionnaire with five Likert scales of learning independence. The students' independence was seen based on the results of the questionnaire. This questionnaire contained 25 statements consisting of six aspects of students' independence (Saefullah, 2013; Farahdina, 2014). Those six aspects are not dependent on others, confidence, initiative, responsibility, motivation, and self-evaluation. Learning independence indicators proposed by Sharma et al., (2010) were simplified into six indicators: (1) do not depend on other people; (2) confidence, (3) initiative; (4) responsibility; (5) motivation; (6) self-evaluation.

In Astalini's research (2019), a Likert scale consists of 5 choices. The rating categories based on the Likert scale are presented in Table 1.

Table 1. The Rating Categories on the Likert Scale

\begin{tabular}{ccc}
\hline No & Score & Item Description \\
\hline 1 & 5 & Strongly agree \\
2 & 4 & Agree \\
3 & 3 & Hesitate \\
4 & 2 & Disagree \\
5 & 1 & Strongly disagree \\
\hline
\end{tabular}

The response scores were calculated using the following equation (1).

$$
N p=\frac{n}{N} x 100 \%
$$

$\mathrm{N}_{\mathrm{p}} \%$ is the expected percentage score, $\mathrm{n}$ is the total score obtained, $\mathrm{N}$ is the maximum scores.

After obtaining the percentage of respondents' answers, the interpretation was 
given from the research results (Kamelta, 2013). The criteria for evaluating the learning independence questionnaire are presented in Table 2.

Table 2. The Criteria for Evaluating Learning Independence

\begin{tabular}{cc}
\hline Interval (\%) & Criteria \\
\hline $0,0<\mathrm{x}<20,0$ & Very low \\
$20,0 \leq \mathrm{x}<40,0$ & Low \\
$40,0 \leq \mathrm{x}<60,0$ & Medium \\
$60,0 \leq \mathrm{x}<80,0$ & High \\
$80,0 \leq \mathrm{x}<100$ & Very high \\
\hline
\end{tabular}

\section{RESULTS AND DISCUSSION}

This research compares students' learning independence after applying the experiment model to the control class and the experimental class. The control class experiments in real terms while the experimental class performs experiments using the virtual experiment model assisted by Tracker.

The research began by providing simulations of how to use tracker software in the experimental class. Questions and answers were performed related to learning independence, such as learning goals and readiness to learn. While doing experiments, students were given an introduction to the concept of linear momentum. They used tracker software to prove the law of conservation of momentum and drawn graphs of collisions in resilient and nonresilient modes.
Students were divided into four groups, in which two groups did the elastic collision experiment, and the other two groups did the inelastic collision experiment. The investigation is done by using the dynamics train tool. There were two dynamics trains (dynamics train $\mathrm{A}$ and dynamic train $\mathrm{B}$ ) that have equal masses move each other in opposite directions until they collide.

On inelastic collisions, the dynamics train A hit the motionless dynamic train B. Students were asked to determine the time before and after the crash using a stopwatch and the distance to calculate the speed of each dynamics train before and after the collision. The gain speed can be used as the determinant for resistance coefficients to prove the type of collision, including elastic collision or inelastic collision. Furthermore, from the results of the experiments, they could prove the law of conservation of momentum.

Students were asked to analyze the data using tracker software to determine the elastic (Figure 1) and inelastic (Figure 2) collision videos in the experimental class. Students are divided into groups similar to the control class. There are four groups doing experiments, three groups analyze elastic collision videos, and two groups analyze inelastic collisions.

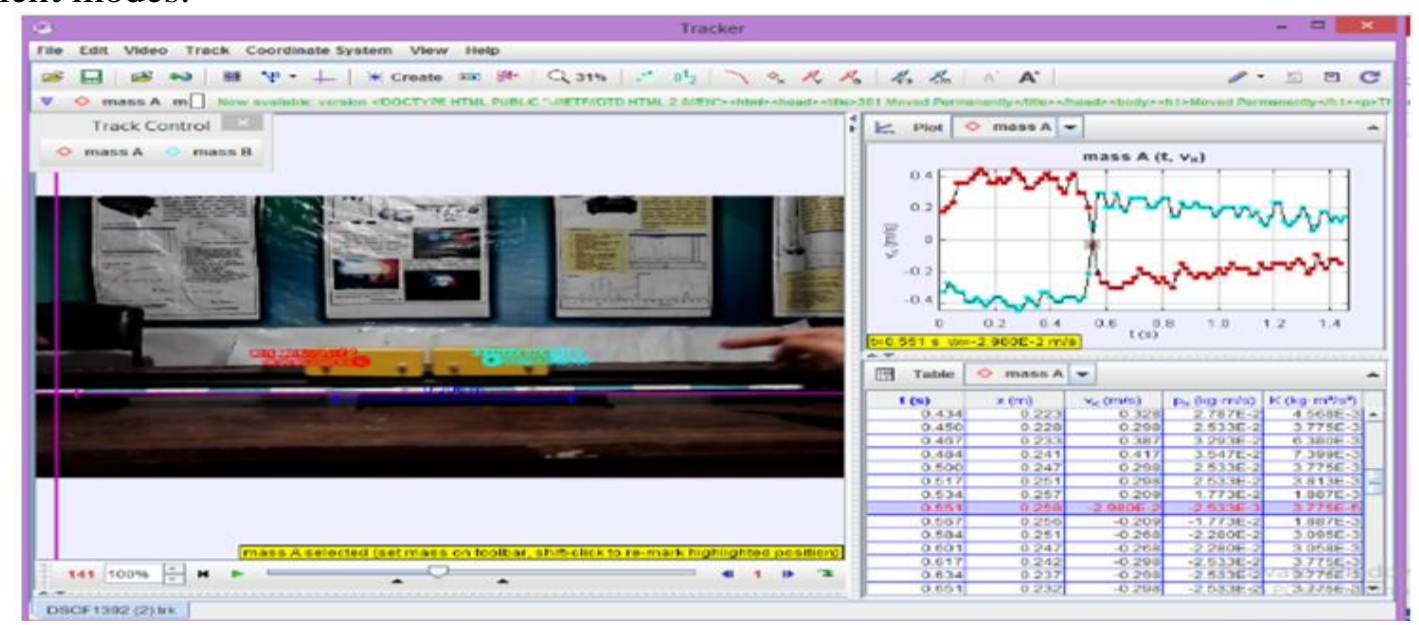

Figure 1. The Elastic Collisions on Tracker 


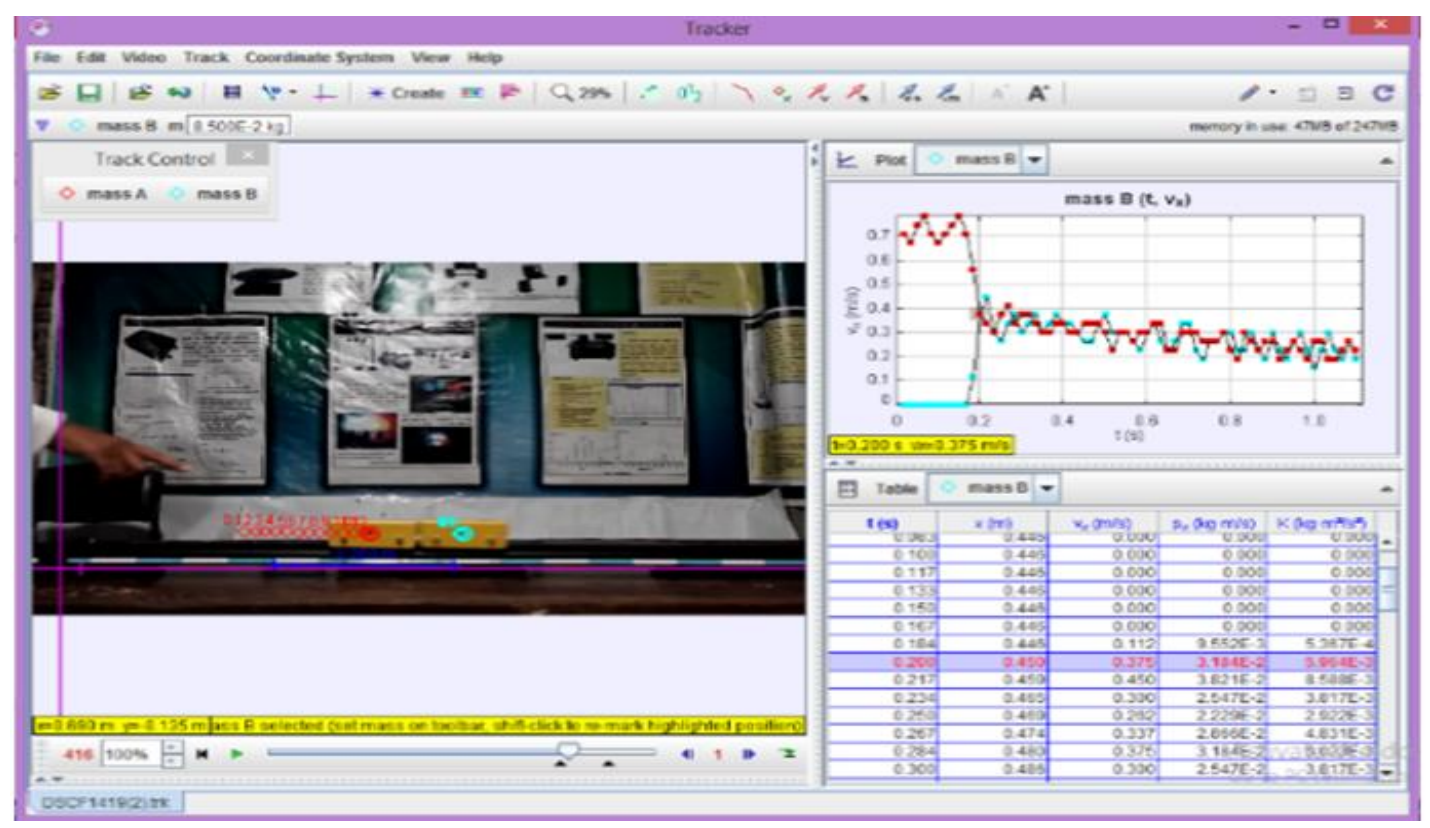

Figure 2. The Inelastic Collisions on Tracker

The results of data analysis were obtained from the Tracker and processed with Excel. While tracking, students obtained the result of video analysis consisting of quantitative data and graphs. The data are velocity (Table 3 ) and resistance coefficient (Table 4).
Table 3. The Data Velocity on Elastic Collisions

\begin{tabular}{ccccccc}
\hline Num & \multicolumn{2}{c}{$\boldsymbol{v}_{\text {beforecollision }}$} & $\boldsymbol{v}_{\boldsymbol{A}^{-}} \boldsymbol{v}_{\boldsymbol{B}}$ & \multicolumn{2}{c}{$\boldsymbol{v}_{\text {aftercollision }}$} & $\boldsymbol{v}_{\boldsymbol{A}^{-}}$ \\
& & & & \multicolumn{4}{c}{$\boldsymbol{v}_{\boldsymbol{B}}$} \\
& $\boldsymbol{v}_{\boldsymbol{A}}$ & $\boldsymbol{v}_{\boldsymbol{B}}$ & & $\boldsymbol{v}_{\boldsymbol{A}}$ & $\boldsymbol{v}_{\boldsymbol{B}}$ & \\
\hline 1 & 0.209 & -0.208 & -0.417 & -0.209 & 0.208 & 0.417 \\
2 & 0.209 & -0.388 & -0.597 & -0.209 & 0.388 & 0.597 \\
3 & 0.397 & -0.387 & -0.784 & -0.397 & 0.322 & 0.719 \\
\hline
\end{tabular}

Table 4. The Data Velocity on Inelastic Collision

\begin{tabular}{ccccccc}
\hline Num & \multicolumn{2}{c}{$\boldsymbol{v}_{\text {beforecollision }}$} & $\boldsymbol{v}_{\boldsymbol{A}} \boldsymbol{v}_{\boldsymbol{B}}$ & \multicolumn{2}{c}{$\boldsymbol{v}_{\text {aftercollision }}$} & $\boldsymbol{v}_{\boldsymbol{A}} \boldsymbol{v}_{\boldsymbol{B}}$ \\
& $\boldsymbol{v}_{\boldsymbol{A}}$ & $\boldsymbol{v}_{\boldsymbol{B}}$ & & $\boldsymbol{v}_{\boldsymbol{A}}$ & $\boldsymbol{v}_{\boldsymbol{B}}$ & \\
\hline 1 & 0.749 & 0 & -0.749 & 0.375 & 0.375 & 0 \\
2 & 0.633 & 0 & -0.633 & 0.372 & 0.372 & 0 \\
3 & 0.679 & 0 & -0.679 & 0.377 & 0.377 & 0 \\
\hline
\end{tabular}

The next step is analyzed in Excel, where students determine the coefficient of resistance and prove the law of conservation of momentum from the results of the Tracker analysis. The data display on Tracker can be seen in Table 5 and Table 6.

Table 5. Display of The Data Resistance Coefficient on Elastic Collisions

\begin{tabular}{ccccc}
\hline Num & $\mathbf{e}_{\text {experiment }}$ & $\mathbf{e}_{\text {average }}$ & $\mathbf{e}_{\text {experiment }}-\mathbf{e}_{\text {average }}$ & $\left(\mathbf{e}_{\text {experiment }}-\mathbf{e}_{\text {average }}\right)^{2}$ \\
\hline 1 & 1 & 0.972363946 & -0.027636054 & 0.000763752 \\
2 & 1 & -1 & 1 \\
3 & 0.917091837 & -0.917091837 & 0.841057437 \\
\hline \multicolumn{4}{r}{$\sum\left(\mathrm{e}_{\text {experiment }}-\mathrm{e}_{\text {average })}\right)^{2}$} \\
\hline \multicolumn{4}{r}{}
\end{tabular}


Table 6. The Data Resistance Coefficient on Inelastic Collisions

\begin{tabular}{|c|c|c|c|c|}
\hline Num & experiment & $\begin{array}{l}\text { everage } \\
\end{array}$ & $\mathbf{e}_{\text {experiment }}-\mathbf{e}_{\text {average }}$ & $\left(\mathbf{e}_{\text {experiment }}-\mathbf{e}_{\text {average }}\right)^{2}$ \\
\hline 1 & 0 & 0 & 0 & 0 \\
\hline 2 & 0 & & 0 & 0 \\
\hline 3 & 0 & & 0 & 0 \\
\hline \multicolumn{4}{|c|}{$\sum\left(\mathrm{e}_{\text {experiment }}-\mathrm{e}_{\text {average }}\right)^{2}$} & 0 \\
\hline
\end{tabular}

The data display both elastic and inelastic collisions are corresponding with the concept of momentum. In this research, students concluded that the linear momentum of a particle or object, which can be modeled as a particle with mass $\mathrm{m}$ and moving with velocity, is defined as the product of mass and velocity. Linear momentum is a vector quantity because it is a scalar quantity $\mathrm{m}$ and vector quantity $\boldsymbol{v}$.

Based on Newton's Second Law, we can connect the linear momentum with the resultant forces acting on the particle (Eq. 2). This shows that the rate of momentum in a particle is equal to the amount of force acting on a particle.

Eq. 2 was used in situations where the velocity vector changes by time changing. It can also be used for phenomena where the mass changes after the collision. Besides, additional revision as a device analysis appears if we apply it for two or more component systems. This generates eternal momentum for the system being developed.

$$
\sum F=m a=m \frac{d v}{d t}
$$

In the Tracker application, we get results in the form of graphs and values. The graph that we observe is a graph of velocity against time. The chart can be understood easily with the help of a Tracker. In addition to the graphs in the table, we can also quickly determine the value of velocity and momentum before the collision, during the crash, and after the crash. This is very helpful for students; therefore, students can learn independently.

In the end, students will get results and conclusions. After the learning process is carried out, the questionnaire sheet was given to students to know the effect of the virtual experiment model on learning independence.

All students should fill out the questionnaire sheet containing 25 statements, both the experimental class and the control class, at the end of the meeting to test the percentage score. For the questionnaire of student learning independence, the researcher used a Likert scale.

Table 7 shows the result analysis of student learning independence based on student independence on control and experiment class.

Table 7. Analysis of Students Learning Independence Questionnaire on Control and Experiment Class

\section{Control Class}

Percentage value $(\%)$

\section{Experiment Class}

Independence Aspects

\section{Criteria}

Percentage value (\%)

$\begin{array}{lc}56.19 & \text { Medium } \\ 60.95 & \text { Medium } \\ 57.90 & \text { Medium } \\ 61.33 & \text { High } \\ 63.61 & \text { High } \\ 65.71 & \text { High }\end{array}$


Based on Table 7, there are four indicators with medium criteria and one indicator with high criteria. Four indicators with criteria do not depend on others, confidence, initiative, responsibility, and motivation. At the same time, the indicator in the high criteria is selfevaluation. Therefore, it can be concluded that the learning class has sufficient learning independence. Analysis of student learning independence based on a questionnaire in the experimental class also can be seen in Table 7. It shows that there are three indicators with medium criteria and three indicators with high criteria. Three indicators with medium criteria are not dependent on others, confidence, and initiative. At the same time, indicators in the high criteria are responsibility, motivation, and selfevaluation. Responsibility aspects obtained a percentage of independence of $61.33 \%$ with high criteria. This aspect consists of 5 statements. Almost the same as the control class, their sense of responsibility is still considered insufficient when viewed from the resolution of the problems they face. This can be seen when using the Tracker, and their results are still not correct. They did not try to solve it themselves but directly asked the researchers. However, students were able to take responsibility for taking notes and reading the material being taught. As seen from the number of students who answered agreed and strongly agreed with the statement, there were ten students. Aspects of motivation, the percentage of independence is $63.61 \%$ with high criteria. This aspect consists of 5 statements. Student motivation can be assessed because, in the student's information, there is a willingness to try to achieve the physics score target that has been set by himself. Twelve students choose to agree on this. Besides, students have enough motivation to set their minimum target score obtained each time a physics test. In statement number 19, eight students agreed and strongly agreed, even though the others still answered doubtfully. Aspects of selfevaluation obtained a percentage of independence of $65.71 \%$ with high criteria.
This aspect consists of 3 statements. Student self-evaluation in the controller class is considered to have reached high criteria. This can be seen from the aspect statement, which states that when answering physics questions and the answer is wrong, students review the answers to fear that something is less thorough. Out of 21 students, 12 students agreed. However, to follow up on this, after the research, the results of the students' posttest tests should be distributed, and students who still answered incorrectly could do an evaluation.

In general, student learning independence in the experimental class is better than in the control class. The experimental class obtained an average of $60.95 \%$ with moderate criteria, while the control class was $51.31 \%$ with moderate criteria. However, both are still in the moderate criteria.

Based on the research that has been done, the independence of students who learn to use Tracker media is better than students who use ordinary experiments. This is shown in the study results that there are three criteria for independent learning in the experimental class: responsible, motivated, selfevaluation, which gets a high percentage of the control class. This is also in line with Trocaru's (2020) research. The activity of analyzing experimental videos can motivate students to learn and find physical events in real life. Besides, it is also mentioned by research based on research conducted by Ediansyah (2019) the use of PBL as long as learning outcomes are at a good level of learning independence, on the results of research and Bernard (2019) independent learning through VBA assisted mathematics learning media for excel games has increased. This is shown by students being more active and responsive when learning. At the time of learning, experiment with the help of Tracker, on average, students have shown aspects that are not dependent on other people. Students can learn independently because they get help from the 
Tracker media during the experiment. Kesuma (2020) also states that the SelfRegulated Learning (SRL) Model can improve students' SRL skills, especially students who are still dependent on others.

Learning through interactive multimedia invites students' interest to know, where students' motivation to learn includes the six aspects of learning independence used by researchers.

\section{CONCLUSION AND SUGGESTION}

Based on the research results, the independence of student learning in the experimental class is better than the class that is not given treatment. It can be said that using a Tracker application more helpful for student learning. Student learning independence was shown from the results based on the questionnaire. In the control class, five aspects get the medium-level independence criteria. It can be concluded that the students' learning independence in the experimental class at AL-AZHAR 14 High School is better than that of the control class. In taking video recordings to be analyzed using the Tracker, a layout and background that highlights the function image are required. The camera layout and lighting settings significantly affect the quality of the video. They impact students' understanding of the symptoms observed from the results of the tracker analysis.

\section{ACKNOWLEDGMENT}

This research received funding support from DIPA Unnes Number 023.17.2677507/2020. We would like to appreciate LP2M Unnes for the support and facilities provided.

\section{REFERENCES}

Adams, N., Hayes, C., Dekkers, A., Elliott, S., \& Atherton, J. (2012). Obtaining learning independence and academic success through self-assessment and referral to a mathematics learning centre. The International Journal of the First Year in Higher Education, 3(2), 21-32.

https://doi.org/10.5204/intjfyhe.v3i2.12 6

Agustriani, E., Hidayati, \& Syafriani. (2018). Penggunaan media berbasis virtual laboratory pada materi momentum terhadap hasil belajar kelas X SMAN 2 Pariaman. Pillar of Physics Education, 11(1), 161-168. https://doi.org/http://dx.doi.org/10.2403 6/2721171074.

Ambarsari, W., Santosa, S., \& Maridi, M. (2013). Penerapan pembelajaran inkuiri terbimbing terhadap keterampilan proses sains dasar pada pelajaran biologi siswa kelas VIII SMP Negeri 7 Surakarta. Jurnal Pendidikan Biologi, 5 (1), 81-95.

Anissofira, A., Latief, F. D. E., Kholida, L., \& Sinaga, P. (2017). Newton's cradle experiment using video tracking analysis with multiple representation approach. Journal of Physics: Conference Series, 895(1). https://doi.org/10.1088/17426596/895/1/012107

Arista, F. S., \& Kuswanto, H. (2018). Virtual physics laboratory application based on the android smartphone to improve learning independence and conceptual understanding. International Journal of Instruction, $11(1)$, 1-16. https://doi.org/10.12973/iji.2018.1111a

Bartholomew, SR (2017). Kebiasaan, persepsi, dan pembelajaran mandiri. International Journal of Self-Directed Learning, 14 (2), 27-44.

Bernard, M., Sunaryo, A., Tusdia, H., Hendriani, E., Suhayi, A., Nurhidayah, N., Parida, M., Fauzi, A. \& Rolina, R. (2019). Enhance learning independence and self ability of exceptional children through developing learning media vba for excel games. Journal of Physics: Conference Series, 1315 (1), 1-11.

Chiriacescu, B., Chiriacescu, FS, Miron, C., 
Berlic, C., \& Barna, V. (2020). Arduino and tracker video-didactic tools for study of the kater pendulum physical experiment. Romanian Reports in Physics, 72(1), 1-14

Ediansyah, E., Kurniawan, DA, Salamah, S., \& Perdana, R. (2019). Investigasi pembelajaran berbasis masalah: Proses pemahaman konsep dan kemandirian belajar pada mata pelajaran statistika penelitian. Humaniora \& Ilmu Sosial Reviews (HSSR), 7(5), 1-11.

Fadholi, L., Harijanto, A., \& Lesmono, A. D. (2018). Analisis video kejadian fisika dengan Tracker software sebagai rancangan bahan ajar momentum dan impuls untuk meningkatkan kemampuan berfikir kritis siswa SMA kelas X. Jurnal Pembelajaran Fisika, $7(3)$, 263-270. https://doi.org/https://doi.org/10.19184/ jpf.v7i3.8598

Fahradina, N., \& Ansari, B. I. (2014). Peningkatan kemampuan komunikasi matematis dan kemandirian belajar siswa SMP dengan menggunakan model investigasi kelompok. Jurnal Didaktik Matematika, 1(2), 54-64.

Hasibuan, A. M., Saragih, S., \& Amry, Z. (2018). Development of learning materials based on realistic mathematics education to improve problem solving ability and student learning independence. International Electronic Journal of Mathematics Education, 14(1), 243-252. https://doi.org/10.29333/iejme/4000

Jian-hua, S., \& hong, L. (2012). Explore the effective use of multimedia technology in college physics teaching. Energy Procedia, 17, 1897-1900. https://doi.org/10.1016/j.egypro.2012.0 2.329

Kamelta, E. (2013). Pemanfaatan internet oleh mahasiswa jurusan teknik sipil fakultas teknik universitas negeri padang. CIived, 1(2), 142-146.

Kesuma, A. T., Harun, Z., Putranta, H., \& Kistoro, H. C. A. (2020). Evaluation of the self-regulated learning model in high schools: A systematic literature review. Universal Journal of Educational Research, 8(10), 47924806

Kholida, L., \& Latief, F. (2018). Investigation of linear momentum and impulse using video analysis. Proceedings of the 1st International Conference on Education Innovation (ICEI 2017), 176-179. https://doi.org/10.2991/icei-17.2018.47

Kinchin, J. (2012). Tracker demonstrates circular motion. Physics Education, 47(1), 15-17. https://doi.org/10.1088/00319120/47/1/F06

Liu, X., \& Li, Q. (2011). Combination of the research-based learning method with the modern physics experiment course teaching. International Education Studies, 4(1), 101-104. https://doi.org/10.5539/ies.v4n1p101

Mulyono, D., Asmawi, M., \& Nuriah, T. (2018). The effect of reciprocal teaching, student facilitator and explaining and learning independence on mathematical learning results by controlling the initial ability of students. International Electronic Journal of Mathematics Education, 13(3), 199205. https://doi.org/10.12973/iejme/3838

Pichailuk, P., \& Luksaneeyanawin, S. (2015). Enhancing learner autonomy in rular young efl learners through projectbased learning: An action research. ABAC Journal, 37(2), 16-32.

Prima, E. C., Mawaddah, M., Winarno, N., \& Sriwulan, W. (2016). Kinematics investigations of cylinders rolling down a ramp using Tracker. AIP Conference Proceedings, 1708. https://doi.org/10.1063/1.4941183

Rabgay, T. (2018). The effect of using cooperative learning method on tenth grade students' learning achievement and attitude towards biology. International Journal of Instruction, 
11(2),

256-280.

https://doi.org/10.12973/iji.2018.11218 a

Rodrigues, M., \& Simeão Carvalho, P. (2014). Teaching optical phenomena with Tracker. Physics Education, 49(6), 671-677. https://doi.org/10.1088/00319120/49/6/671

Rohmah, M., \& Sutiarso, S. (2017). Analysis problem solving in mathematical using theory newman. EURASIA Journal of Mathematics, Science and Technology Education, 14(2), 671-681. https://doi.org/10.12973/ejmste/80630

Sartika, Y., Wahyudi, I., \& Abdurrahman, A. (2019). Using guided inquiry learning with tracker application to improve students' graph interpretation ability. Tadris: Jurnal Keguruan Dan Ilmu Tarbiyah, 4(1), 17-25. https://doi.org/10.24042/tadris.v4i1.306 0

Semerci, A. \& Aydin, M. K. (2018). Examining high school teachers attitudes towards ICT use in education. Internatinal Journal of Progressive Education, 14(2), 93-105.

Sharma, M. D., Johnston, I. D., Johnston, H., Varvell, K., Robertson, G., Hopkins, A., Stewart, C., Cooper, I., \& Thornton, R. (2010). Use of interactive lecture demonstrations: A ten year study.
Physical Review Special Topics Physics Education Research, 6(2), 1-9. https://doi.org/10.1103/PhysRevSTPE R.6.020119

Sulisworo, D., \& Sutadi, N. (2017). Science learning cycle method to enhance the conceptual understanding and the learning independence on physics learning. International Journal of Evaluation and Research in Education (IJERE), 6(1), 64. https://doi.org/10.11591/ijere.v6i1.634 8

Trocaru, S., Berlic, C., Miron, C., \& Barna, V. (2020). Using tracker as video analysis and augmented reality tool for investigation of the oscillations for coupled pendula. Romanian Reports in Physics, 72(1).

Van Halem, N., Klaveren, C. van, Drachsler, H., Schmitz, M., \& Cornelisz, I. (2020). Tracking patterns in self-regulated learning using students' self-reports and online trace data. Frontline Learning Research, 8(3), $140 \quad$ - 163. https://doi.org/10.14786/flr.v8i3.497

Wee, L. K., Tan, K. K., Leong, T. K., \& Tan, C. (2015). Using tracker to understand "toss up" and free fall motion: A case study. Physics Education, 50(4), 436442. https://doi.org/10.1088/00319120/50/4/436 